REISIGL, M. - WODAK, R.: Discourse nad Discrimination: Rhetorics of Racism and Antisemitism. London; New York: Routhledge, 2001. ISBN 978-0-41-523150-3.

SPITZMÜLLER, J. - WARNKE, I. H.: Diskurslinguistik. Eine Einführung in Theorien und Methoden der transtextuellen Sprachanalyse. Berlin-Boston: De Gruyter, 2011. ISBN 978-3-11-021244-0.

VAN DIJK, T. A.: Critical Discourse Studies: A Sociognitive Approach. In: WODAK, R. MEYER, M. (eds): Methods of Critical Discourse Analysis. Second Edition. Los Angeles; London; New Delphi; Singapore; Washington DC: Sage Publications, 2010, s. $62-86$.

VAN DIJK, T. A.: Ideology: A Multidisciplinary Approach. London; Thousand Oaks; New Delphi: Sage Publications, 1998. ISBN 0-7619-5655-7.

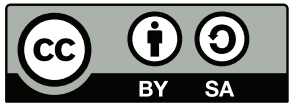

This work can be used in accordance with the Creative Commons BY-SA 4.0 International license terms and conditions (<https://creativecommons.org/licenses/by-sa/4.0/legalcode>). This does not apply to works or elements (such as images or photographs) that are used in the work under a contractual license or exception or limitation to relevant rights.

https://doi.org/10.5817/OS2019-4-10

\title{
Život ve slovech, slova v životě
}

KLOFEROVÁ, S. - ŠIPKOVÁ, M. (eds): Život ve slovech, slova v životě. Procházka labyrintem českých nářečí. Praha: NLN, 2018. 210 s. ISBN 978-80-7422-657-1.

Stalo se již tradicí, že pracovníci Ústavu pro jazyk český Akademie věd České republiky informují o výsledcích své vědecké práce nejen odborníky, ale i širší veřejnost. Tyto popularizační aktivity se setkávají s velice př́ínivým ohlasem, jak o tom svědčí např. dvoudílný Divnopis, ${ }^{1}$ včetně z něho vycházejících pořadů České televize, ze starších publikací pak třeba Čeština všední $i$ nevšedni $i^{2}$ a mnoho dalších. Tuto řadu nedávno obohatila knížka Život ve slovech, slova $v$ životě s podtitulem Procházka labyrintem českých nářčči, ${ }^{3} \mathrm{v}$ níž prezentují některé výsledky svého bádání

1 JANÁČ, M. - TUMLÍŘ, P. - HARVALÍK, M.: Divnopis: proč se to tak jmenuje? 1. Praha: Radioservis ve spolupráci s Českým rozhlasem, 2006. JANÁČ, M. - TUMLÍ̌̉, P. - HARVALÍK, M.: Divnopis: proč se to tak jmenuje? 2. Praha: Radioservis ve spolupráci s Českým rozhlasem, 2008.

2 KUCHAR̆,J. a kol.: Čeština všední i nevšední: čtvrtý výběr jazykových koutků Čs. rozhlasu $z$ dialektologie, frazeologie a onomastiky. Praha: Academia, 1972.

3 KLOFEROVÁ, S. - ŠIPKOVÁ, M. (eds): Život ve slovech, slova v životě. Procházka labyrintem českých nárečí. Praha: NLN, 2018. 
uskutečněného v rámci řešení grantového projektu Odraz života našich předků $v$ mizejících slovech pracovnice dialektologického oddělení.

Hned v úvodu konstatují, že „svět tradičních nářečí nám pozvolna mizí před očima“, a poté $\mathrm{v}$ chronologickém sledu uvádějí přehled některých soustavnějších názorů o zániku nářečí a jeho příčinách. Sama publikace však šiří prezentovaného materiálu dokazuje, že navzdory všem prognózám nedocházelo (a naštěstí stále nedochází) $\mathrm{k}$ ústupu nářečí tak rychle, celoúzemně a ve všech komunikačních situacích, takže i v dnešních dialektech lze stále objevovat četné a nesmírně zajímavé náměty $\mathrm{k}$ dalšímu bádání a odkrývání nových, dosud neznámých souvislostí.

Autorky mají v oboru bohaté zkušenosti nabyté již při zpracovávání šestisvazkového Českého jazykového atlasu ${ }^{4}$ a postupně prohlubované prací na široce koncipovaném Slovníku nářč́i českého jazyka i na Slovníku pomístních jmen na Moravě a ve Slezsku ${ }^{6}$. Materiálovým východiskem jsou jim obsáhlé databáze systematicky budované několika generacemi našich dialektologů (především Archiv lidového jazyka s cca 1,5 milionem nářečních dokladů), které průběžně doplňují výsledky vlastních sondačních výzkumů realizovaných v současné době ve vybraných lokalitách po celém území českého národního jazyka. Bohatě využívají rovněž poznatků dialektologické literatury a řady dalších etymologických, onomastických, etnografických aj. prací.

Publikace obsahuje celkem 33 příspěvků, které jsou řazeny podle volnějších věcněvýznamových souvislostí do větších celků, jako je např. čarování, nemoci a lidové léčitelství, domácnost, vaření a pečení. Zvláštní část je věnována pomístním jménům. Šiře zpracovávaného materiálu určuje i rozsah jednotlivých kapitol - od témat velice obsáhlých (např. někdejší podomní obchod) až po drobnější, avšak neméně zajímavé postř̌ehy (kotovice versus Kotovice vycházející z novinové zprávy s informací, že majitelé „přivezli materiál k rekonstrukci své chalupy z Kotovic“, svědčící o neznalosti významu dialektismu kotovice ,nepálená cihla').

Při analýze přičin zániku slov autorky bohatě materiálově dokládají jak pojmenování zanikající spolu s reáliemi (hyclík, sousek), tak slova mizející s potřebou přesnější specifikace v pojmenování (chlejsták, špráchanec) i názvy mající povahu termínů, které se vytrácejí především vlivem spisovného jazyka při školní výuce (pámbičkova kravička, psí jazyk). Pozornost věnují výrazům cizího původu, převážně německého (šmak, košt), ale i jinojazyčného (domikát, kotár) i vzájemnému ovlivňování názvů, k němuž dochází zprav. v př́hraničních oblastech (žebráky na Náchodsku

4 Český jazykový atlas 1-5. Dodatky. <http://cja.ujc.cas.cz>. [online]. [Cit. 13. 10. 2019].

5 Slovník nářečí českého jazyka. <http://sncj.ujc.cas.cz>. [online]. [Cit. 13. 10. 2019].

6 Slovník pomístních jmen na Moravě a ve Slezsku. <http://spjms.ujc.cas.cz>. [online]. [Cit. 13. 10. 2019]. 
korespondující s polským dziady nebo lepiki $\mathrm{v}$ někdejších německých nářečích v Poohří, v sousedství areálu českého pojmenování lepíky).

Nejen zasvěcený dialektolog pozná, že současnou práci na celonárodním nářečním slovníku nejmarkantněji odrážejí prríspěvky zaměřené sémaziologicky, objasňující např. územně rozrůzněné významy slov boží a čistý. V obecném povědomí zajisté nejsou ani významové specifikace spojení je boží, které v závislosti na konkrétním místě výskytu může znamenat, omdlel', ,právě usnul', ,tvrdě spí, nebo dokonce ,je opilý:

Při prezentaci zajímavých typů pomístních jmen autorky často polemizují s věrohodností tzv. lidových etymologií. K odhalení původních pojmenovávacích motivací se postupně propracovávají studiem historických pramenů osvětlujících někdejší souvislosti, které vedly $\mathrm{k}$ vzniku pomístních jmen, např. Hádka a Hátka. Tato pomístní jména jsou zároveň důkazem, že $\mathrm{k}$ řadě závěrů lze dospět až vzájemnou konfrontací poznatků dialektologických (i jazykovězeměpisných) a onomastických.

Kniha poskytuje také (pro neodborníky zajisté potřebné) vysvětlení různého způsobu zápisu nářečních výrazů. $V$ závěru je doplněna obsáhlým seznamem literatury, soupisem elektronických zdrojů, zkratkami odkazované literatury, zkratkami okresů a zkratkami jmen autorek. Obsahuje anglické resumé.

Publikace vědecky fundovaným způsobem představuje výsledky současného dialektologického bádání a zhodnocuje a zpř́ístupňuje poznatky získané předchozími generacemi dialektologů. Ocenění si zaslouží také pro neobvyklou šíři shromážděného materiálu, který je prezentován formou př́stupnou i laické veřejnosti. Kromě prínosu ryze vědeckého nám prostřednictvím slov, slovních spojení i frazémů přibližuje naprosto unikátní a postupně mizející část lexikální zásoby našeho národního jazyka a poskytuje i cenné informace o životě našich předků. V současné éře obecně se uplatňujících globalizačních tendencí tak přispívá k naplnění požadavku zachovávání nehmotného kulturního dědictví jednotlivých etnik v sjednocující se Evropě.

Farmila Bachmannová

\section{Bibliografie:}

JANÁČ, M. - TUMLÍŘ, P. - HARVALÍK, M.: Divnopis: proč se to tak jmenuje? 1. Praha: Radioservis ve spolupráci s Českým rozhlasem, 2006. ISBN 80-86212-47-5. JANÁČ, M. - TUMLÍR̆, P. - HARVALÍK, M.: Divnopis: proč se to tak jmenuje? 2. Praha: Radioservis ve spolupráci s Českým rozhlasem, 2008. ISBN 978-80-86212-61-6. KLOFEROVÁ, S. - ŠIPKOVÁ, M. (eds): Život ve slovech, slova v životě. Procházka labyrintem českých nářečí. Praha: NLN, 2018. ISBN 978-80-7422-657-1. 
KUCHAR̆, J. a kol.: Čeština všední i nevšední: čtvrtý výběr jazykových koutků Čs. rozhlasu $z$ dialektologie, frazeologie a onomastiky. Praha: Academia, 1972.

Český jazykový atlas 1-5. Dodatky. <http://cja.ujc.cas.cz>. [online]. [Cit. 13. 10. 2019]. Slovník nárečí českého jazyka. <http://sncj.ujc.cas.cz>. [online]. [Cit. 13. 10. 2019].

Slovník pomístních jmen na Moravě a ve Slezsku. <http://spjms.ujc.cas.cz>. [online].

[Cit. 13. 10. 2019].

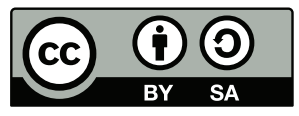

Toto dílo Ize užít v souladu s licenčními podmínkami Creative Commons BY-SA 4.0 International (<https:// creativecommons.org/licenses/by-sa/4.0/legalcode>). Uvedené se nevztahuje na díla či prvky (např. obrazovou či fotografickou dokumentaci), které jsou v díle užity na základě smluvní licence nebo výjimky či omezení príslušných práv.

\section{https://doi.org/10.5817/OS2019-4-11}

\section{Вечно живой... сленг}

SZCZERBOWSKI, T.: Polskie i rosyjskie stownictwo slangowe. Krakow: Wydawnictwo Naukowe Uniwersytetu Pedagogicznego im. Komisji Edukacji Narodowej w Krakowie, 2018, 392 s. ISBN 978-83-8084-210-6.

Новая книга известного польского лингвиста Тадеуша Щербовского под названием «Польская и русская сленговая лексика» (Polskie i rosyjskie stownictwo slangowe), безусловно, привлечет внимание исследователей языка, в сферу научных интересов которых входит субстандартная лексика. Монография вышла на польском языке в 2018 году в Кракове. Как следует из названия книга посвящена сленгу. Главной целью, - отмечает автор, - был анализ культурно обусловленных механизмов образования и функционирования сленговой лексики в польском и русском языках. Во введении говорится, что книга посвящена способам общения в неофициальных ситуациях, когда передаваемая информация носит экспрессивный характер и подчеркивает существование особого рода дискурсов - общности, рассматриваемой как своя (МЫ) и противопоставленной другим (ОНИ), чаще всего по параметрам возраста (молодежь), выполняемой профессии, способам проводить время, не только свободное. Эти средства и способы общения не являются отдельными языками, конкурирующими с языком общенациональным, они не могут полностью заменить его, т. к. являются частью языка, которая не считается образцовой или стандартной ${ }^{1}$.

1 SZCZERBOWSKI, T.: Polskie i rosyjskie stownictwo slangowe. Krakow: Wydawnictwo Naukowe Uniwersytetu Pedagogicznego im. Komisji Edukacji Narodowej w Krakowie, 2018, c. 7. 